\title{
Nuda podróżowania, nuda czekania. „Gerry” Gusa Van Santa a teatr Samuela Becketta
}

Roger Ebert w swojej recenzji filmu Gerry Gusa Van Santa wspomina, jak tuż po jego projekcji na festiwalu Sundance w 2002 roku wdał się w rozmowę z trzema kobietami, które ku jego zdziwieniu uznały ów obraz za „egzystencjalny” oraz całkiem podobny do Czekając na Godota Samuela Becketta. „W Godocie - powiedziała jedna z nich bohaterowie czekają i czekają i Godot nigdy nie przychodzi. W Gerry'm idą i idą i nigdzie nie docierają" $\left.{ }^{1}\right]$.

Jakkolwiek błaha i zabawna (zwłaszcza w intencji relacjonującego ją autora) by się ta uwaga nie wydała, myślę, że jednak coś się za nią kryje, zwłaszcza że spostrzeżenie to podzielają również inni recenzenci. Todd Konrad posunął się nawet do stwierdzenia, że „pod wieloma względami Gerry zawdzięcza wiele teatrowi absurdu Samuela Becketta. Czas mija, ludzie błąkają się, ale ostatecznie nic się nie dzieje, życie po prostu posuwa się dalej, bez zawahań i objazdów. Gdyby szukać kinowego ekwiwalentu Czekając na Godota, Gerry mógłby zgłosić swą kandydaturę" [2]

Jak pokazała jedna z podsłuchanych przez Eberta pań, wystarczy w zasadzie jedno zdanie, żeby streścić fabułę filmu Van Santa. Ale według słów Tadeusza Sobolewskiego Gerry'ego cechuje „zwodnicza prostota"[3]. Czy kluczem do przeniknięcia tajemnicy tego obrazu może stać się teatr Samuela Becketta? Dla pisarza punktem wyjścia było przecież pustkowie - ogołocona scena. W ten sposób udowadniał, że to, co pozornie nieważne i zazwyczaj pomijane, również może być nośnikiem znaczenia.

Zacznijmy więc od owego streszczającego zdania, które posłużyło jednej z kobiet do podsumowania filmu Gerry. Czy w istocie nie mogłoby ono zostać zastąpione sentencją św. Augustyna, która tak zafascynowała Becketta wspaniałością swej formy, że posłużyła za punkt wyjścia dla Godota? Wyzierająca z niej symetria, ewokująca iście Blake’owską „skupioną grozę”, wydała się pisarzowi doskonała. Nie tylko w jej architektonicznym, formalnym aspekcie, ale również jako punkt wyjścia dla szczególnej wizji człowieka i otaczającego go świata[4].

[1] R. Ebert, Gerry, http://rogerebert.suntimes.com/ apps/pbcs.dll/article?AID=/20030228/REVIEWS/ 302280304/1023 (przeł. J.P.).

[2] T. Konrad, Gerry, http://www.independentfilm quarterly.com/ifq/reviews/think-gerry.htm (przeł. J.P.).
[3] T. Sobolewski, Niezwykly film Gusa Van Santa, http://wyborcza.pl/1,75475,1438291.html.

[4] A. Libera, Wstęp, w: S. Beckett, Dramaty, przeł.

A. Libera, Wrocław 1995, s. XLV. 
„Nie rozpaczaj: jeden z łotrów został zbawiony. Nie pozwalaj sobie: jeden z łotrów został potępiony" [5].

Sugeruje ona podwojonego bohatera, parę; układ obecny choćby w Czekając na Godota (Vladimir i Estragon, Pozzo i Lucky) czy Końcówce (Hamm i Clov, Nagg i Nell). Jan Błoński wyróżnia dwie odmiany Beckettowskiej pary[ $\left.{ }^{6}\right]$. Mogą tworzyć ją albo dwa współrzędne podmioty (przyjaciele), albo kat i ofiara. Relacja łącząca dwóch błądzących po pustyni bohaterów filmu Van Santa jest jednak ambiwalentna. Trudno uporządkować ją według takiego kryterium, wydaje się ona bowiem realizować jednocześnie obie powyższe opcje. Z jednej strony nie sposób wątpić w łączącą bohaterów przyjaźń i wzajemną troskę o siebie nawzajem, objawioną choćby w scenie skakania ze skały. Z drugiej zaś wspólnota zagadkowej konieczności, jaka łączy również postacie Becketta (czekanie, umieranie), staje się w ich przypadku narzędziem rozkładu. Z czasem zaczynamy dostrzegać, że jeden z mężczyzn (grany przez Matta Damona) wyraźnie zaczyna nad drugim (Casey Affleck) dominować. Przejmuje inicjatywę w podejmowaniu decyzji; zarówno psychicznie, jak i fizycznie lepiej znosi trudne warunki. Choć zachowanie obu bohaterów w kulminacyjnej scenie jest niejednoznaczne (próba przytulenia czy może wzajemnego uduszenia, gest miłosny czy zbrodniczy?), faktem jest, że kończy się to śmiercią jednego z nich. Być może wątpliwość ta zostaje zasiana celowo, bo interpretując stosunek Hamma do Nagga w Końcówce, Błoński zwraca uwagę, że okrucieństwo może być „rozpaczliwą ucieczką przed nieubłaganą koniecznością zagłady"[7], impulsem w perspektywie przeczuwanego bliskiego końca. Ale zarazem, analizując dynamikę związków u Becketta, wyprowadza on przemoc z pożądania właśnie $\left.{ }^{8}\right]$. Potwierdza tym samym nierozerwalność odwiecznej pary Eros - Tanatos.

Tadeusz Sobolewski dostrzega w filmie podtekst gejowski, widząc w eskapadzie bohaterów próbę ucieczki przed społecznymi regułami, szukanie na bezdrożach oazy wolności seksualnej. Jak pisze, „stajemy się świadkami wzajemnej relacji, która z początku wygląda na kumpelską. Jednak w grę wchodzi związek bliższy, być może niespełniony, gdzie jedna strona jest silniejsza, a druga słabsza; jedna dominuje, druga ulega. Wycieczka staje się alegorią tego związku" [9]. Podobne sugestie wysuwano także wobec Czekając na Godota. U Vladimira odnajdziemy więcej cech stereotypowo przypisywanych mężczyznom, Estragona natomiast charakteryzują cechy pospolicie uważane za kobiece. Symptomatyczne w tym świetle wydaje się spostrzeżenie Błońskiego, że „mężczyźni Becketta mają w ogóle więcej energii i więcej nadziei, ale także - więcej goryczy i woli niszczenia. Mniej są pogodzeni z losem niż kobiety [...]. One bowiem [...] łatwiej godzą się na

[5] Ibidem, s. XLIII.

[6] J. Błoński i M. Kędzierski, Samuel Beckett, Warszawa 1982, s. 25 .
[7] Ibidem, s. 27 .

[8] Ibidem, s. 25.

[9] T. Sobolewski, op. cit. 
wyrok" [10]. Idąc dalej tym tropem, możemy również odczytać utwory Becketta i Van Santa jako metafory rozdarcia, dualistycznego zmagania się ze sobą dwóch (stąd para jako bohater) aspektów - czy to męskości z kobiecością, ciała z duszą, czy to nawet dobra ze złem. Wówczas zniknąłby bratobójczy wymiar finału jako zbrodni Kaina na Ablu. Wyprawa na pustynię stałaby się wtedy swoistym obrzędem przejścia dokonanym w odosobnieniu. Pojedynkiem, z którego zwycięsko wychodzi silniejsza część osobowości. Tylko która to część? Który łotr zostaje zbawiony - ten, który przeżył, czy ten, który zginął?

Podział ról bohaterów na zasadzie skontrastowanych cech przywodzi na myśl również slapstickowe duety aktorskie, takie jak Laurel i Hardy (Flip i Flap). Fizyczna komedia oparta na kaskaderskich gagach rodem z filmów Charliego Chaplina i Bustera Keatona to tradycja odzywająca się nieraz w twórczości Samuela Becketta. Estragon i Vladimir przypominają wręcz klaunów, Lucky i Pozzo kilkakrotnie się przewracają; postacie plączą się w słowach i ruchach, zastygając gdzieś pomiędzy niezgrabnością gestów a ich celebrowaną starannością. W zrealizowanym na podstawie jedynego scenariusza pisarza Filmie (1965) w reżyserii Alana Schneidera główną rolę odgrywa sam Buster Keaton, co nie pozostaje bez związku z obrazem Gusa Van Santa. Wspomniana już scena, kiedy to jeden z bohaterów zmuszony jest zeskoczyć ze stromej skały, na której utknął nieoczekiwanie dla samego siebie, stanowi szczególny hołd dla aktora słynącego nie tylko $\mathrm{z}$,kamiennej twarzy”, ale i z niezwykle niebezpiecznych numerów kaskaderskich. Jak pisze Roger Ebert, Keaton w swoich filmach nieustannie „spada i spada i spada [...]: z okien na drugim piętrze, z krawędzi urwisk, drzew, pociągów, motocykli, balkonów. Upadki te nie są zazwyczaj fałszowane: ląduje, wstaje, idzie dalej" [11]. Podobnie Casey Affleck w Gerry'm - zeskoczywszy ze skały, podejmuje dalszą wędrówkę przez pustynię.

Ale dokąd tak wędruje? - chciałoby się spytać. Przecież zanim dwaj amerykańscy młodzieńcy zaczną błądzić w poszukiwaniu miejsca, gdzie zostawili samochód, mają wyznaczony pewien określony cel, ku któremu zmierzają. Określony, choć zarazem doskonale niedookreślony - nazywany przez nich Czymś („The Thing”). Jeszcze raz wróćmy do anegdoty Rogera Eberta:Vladimir i Estragon nie doczekują przybycia swojego Godota, podobnie jak dwóch „Gerrych” nie dociera do owego Czegoś. Czy jednak ostatecznie nie doznają oni właśnie Czegoś, czymkolwiek by To nie było - śmiercią, końcem (Końcówką?), zbawieniem? Dotknięciem Tajemnicy doświadczonym w kontakcie z potęgą i grozą przyrody (jak w Pikniku pod wisząca skałą Petera Weira)? A może tylko poczuciem zagubienia? Być może zarówno Coś, jak i Godot to doskonałe McGuffiny, fetysze co prawda napędzające ciąg

[10] J. Błoński, op. cit., s. 48.

[11] R. Ebert, The Films of Buster Keaton (1923), http://
rogerebert.suntimes.com/apps/pbcs.dll/article?AID=/ 20021110/REVIEWSo8/40802001/1023 (przeł. J.P.). 
wydarzeń, ale w swej istocie nieważne, nawet nieobecne. John Perreault to Van Santowskie Coś nazywa nawet „anty-McGuffinem” w takim sensie, że zamiast napędzać fabułę, ono ją po prostu przetrzymuje [12], nietknięte wzrokiem ani wiedzą widza.

Niedookreśloność w Gerry'm zaczyna się w zasadzie już na poziomie samego tytułu. Cóż on bowiem oznacza? Czy słowo „Gerry” nazywa osobę czy czynność? Jego enigmatyczność przywodzi na myśl imię istoty (?) oczekiwanej przez dwójkę postaci w najsłynniejszym dramacie Becketta. Gus Van Sant opowiada, że wzięło się ono z prywatnego żartu - zabawy Matta Damona i Casey’ego Afflecka, którzy

znaleźli naprawdę zabawne zdjęcie obwieszonego złotymi łańcuchami salonowego śpiewaka Gerry’ego Woo i zaczęli nazywać siebie Gerry. Kolejny Gerry był nauczycielem teatralnym. Niektórzy „Gerry’owie” byli dobrzy, inni źli. Ostatecznie oznaczało to: źle! Zły wizerunek: skrzywiony, spieprzony. Przezywali się nawzajem Gerry w sensie hej, spieprzaj![13]

W efekcie bohaterowie filmu pozostają bezimienni, a tytułowe słowo w ich ustach może być zarówno czasownikiem, jak i rzeczownikiem, pseudonimem i inwektywą. Gerry jest więc tytułem reprezentującym (wyróżniony w twórczości Becketta przez Antoniego Liberę[14]) typ „wewnętrzny” wobec tekstu. Wywodzi się on bowiem z samej jego materii, ma charakter powracającego słowa - klucza, słowa - refrenu, podobnie jak w Końcówce czy Katastrofie.

Zresztą, czy słowa mają tu jeszcze jakieś znaczenie? Absurdalność rozmów prowadzonych przez bohaterów Becketta udziela się również dwóm podróżnikom Van Santa. „Przestrzeń literacka zostaje wypełniona słowami jak pustynia piaskiem" [15], pisze Błoński o twórczości Irlandczyka i zastanawiająca jest zbieżność tej metafory z miejscem akcji Gerry'ego. Tylko że w ułomnych rozmowach Beckettowskich postaci prześwitują gdzieniegdzie jeszcze próby dotarcia do jakiejś głębi. Vladimir i Estragon początkowo rozprawiają co prawda o za ciasnym bucie, ale już po chwili próbują zmierzyć się z sentencją biblijną. Gerry i Gerry nawet nie podejmują takich prób, ich rozmowy oscylują wokół teleturniejów i gier komputerowych; jest trochę tak, jakby pustynny krajobraz symbolizował ich wnętrza. Czy taka psychizacja krajobrazu jest dla Van Santa środkiem do zbudowania metafory ponowoczesności jako świata po katastrofie (trochę jak w Końcówce)? Może owe zabawy językiem, gra w "Gerry'ego” czy absurdalne dyskusje o wytworach popkultury albo o terytoriach godowych dzikich zwierząt to właśnie usiłowanie dotarcia do zagubionych wartości, próba obalenia władzy, której narzędziem jest język? Próba wydzielenia sobie zakątka wolności? Według Rolanda Barthesa, „jeśli zwie się wolnością nie tylko możność wymykania się władzy, ale również

[12] J. Perreault, Gerrymandering, http:// 209.85.129.132/search?q=cache:guDI1uG8n48J:www. johnperreault.com/id6.html+beckett+gerry+van+ sant\&hl $=\mathrm{pl} \& \mathrm{ct}=\mathrm{clnk} \& \mathrm{~cd}=7 \& \mathrm{gl}=\mathrm{pl}$.
[13] G. Peary, Gus Van Sant, http://www.geraldpeary. com/interviews/stuv/van-sant.html (przeł. J.P.).

[14] A. Libera, op. cit., s. CII.

[15] J. Błoński, op. cit., s. 30. 
i przede wszystkim możność całkowitej niezależności, wolność jest dostępna poza językiem”[16]. Ale Barthes dodaje także, że „na nieszczęście ludzki język nie ma zewnętrza: to drzwi bez klamki, można zeń wyjść tylko za cenę szaleństwa” [17].

Nie ulega jednak wątpliwości, że nasi bohaterowie usiłują kontestować, jakkolwiek jałowe by ich starania nie były. Czy nie dlatego właśnie zbaczają ze szlaku, że - jak mówi jeden z nich - „wszystkie drogi prowadzą do Czegoś” (niczym do Rzymu)? Zejście z wydeptanej ścieżki jest świadectwem sprzeciwu. Skoro ścieżki są narzucone, bezpieczne - porzućmy je!

W filmach Gusa Van Santa wielokrotnie odzywa się tradycja bitnikowska (w Drugstore cowboy pojawia się nawet William Burroughs) oraz mitologia amerykańskiego kina drogi. Ich zasadą jest bunt przeciw sztywnemu gorsetowi ładu społecznego, mieszczańskim schematom myślenia i wstrzemięźliwej obyczajowości. Wolność stanowi najwyższą wartość, utożsamiona jest z pędzącym z zawrotną prędkością po autostradzie samochodem. Ale, jak zauważa Tadeusz Sobolewski, „Van Sant zarazem polemizuje z tą tradycją. Jest przedstawicielem - już 50-letnim - innej generacji, dla której doznanie wolności nie jest punktem dojścia, lecz wyjścia”[ $\left.{ }^{18}\right]$. Warto zauważyć, że właściwym początkiem podróży bohaterów Gerry'ego jest właśnie akt porzucenia samochodu na rzecz pieszej wędrówki.

Postacie filmu stają się wówczas podobne do Deleuzejańskich nomadów. Jak pisze Małgorzata Jakubowska,

nomadyczne rozprzestrzenianie się po danym terenie jest zmienne i wolne, polega na przemieszczaniu się, swobodnym wypełnianiu dowolnej przestrzeni, rozdzielaniu się w niej, nie zaś na jej podziale [...]. Świat nomada oparty jest na równorzędności elementów , nie zawiera uprzywilejowanej części w postaci centrum, jest kwintesencją wielośrodkowości, nie ma początku ani końca, nie ma granic [19].

\section{Pozwala to na}

oderwanie myśli od terytorium, całkowite wyzwolenie z ograniczeń myśli osiadłej. Myślenie w tym systemie jest przygodą, jest otwarte na niewiadomą, stawia pytania nie znając odpowiedzi. Nigdy nie ma pewności, dokąd zaprowadzą ją podjęte poszukiwania. Myśl taka staje się niebezpieczna, nie respektuje wyznaczonych zewnętrznych ustaleń, nie zawiera apriorycznego ładu ani żadnej arché, która by ten ład wyznaczała. Stąd Deleuze określa ją jako czysto anarchiczną. Tak ukształtowana myśl może zwrócić się przeciwko instytucjom i instancjom, może zwrócić się przeciwko samemu myślicielowi[ $\left.{ }^{20}\right]$.

Wyzwoleńcze, eskapistyczne zapędy bohaterów faktycznie obracają się przeciwko nim, obaj płacą wysoką cenę za swoją próbę.

[16] R. Barthes, Wyktad, przeł. T. Komendant, „Teksty" 1979 , nr 5, s. 12.

[17] Ibidem.

[18] T. Sobolewski, op. cit.

[19] M. Jakubowska, Gilles Deleuze (postmoderni- styczna teoria kina), w: Alicja Helman i Jacek Ostaszewski, Historia myśli filmowej. Podręcznik, Gdańsk 2007, s. 332.

[20] M. Jakubowska, Teoria kina Gillesa Deleuze'a, Kraków 2003, s. 32. 
Kara wymierzana człowiekowi w twórczości Becketta spada na niego w postaci czasu, który unieruchamia go swoją powtarzalnością bądź uruchamia w nim fatalistyczny proces degradacji, gdzieś na horyzoncie którego czai się nieubłagane widmo śmierci[21]. Jak dostrzega Jan Błoński - czas w sztukach Irlandzkiego pisarza „objawia się niemal namacalnie: jest jakby kleistą substancją, oblepiającą słowa i działania. Unaocznia go zaś powolność: los bohaterów jest żmudą i cierpliwością [...]. Beckett nie ma sobie równego w rozszczepianiu, wydymaniu, spowalnianiu scenicznego działania" [22].

Van Sant wydaje się podążać w tym względzie śladami Becketta - podstawowym zabiegiem unieruchamiającym czas jest u niego doprowadzenie akcji, ekranowego dziania się do minimum - jak już dostrzegliśmy, opowiedzenie fabuły filmu zajmuje dosłownie chwilę. Zwięzłość takiej relacji pozostaje oczywiście w jawnej sprzeczności z wydłużonym trwaniem ukazanych wydarzeń. W Gerry’m „nic się przecież nie dzieje”, i to nie dzieje do tego stopnia, że samo owo „niedzianie” staje się zasadą „rozwoju” wydarzeń. Rolę afabularności jako chwytu unieruchamiającego czas potwierdzają słowa Przemysława Czaplińskiego - „co nie ma swojej fabuły, nie ma początku i końca, jest więc nieskończone”[23].

W ustach Tadeusza Sobolewskiego taki zabieg autorski zyskuje wręcz znamiona manifestu nomadologicznego, gdyż „fabuła filmowa tworzy system znaków i strzałek, zapewniających bezpieczne poruszanie się po niezbadanych terenach"[24], a amerykański reżyser takie rusztowanie odrzuca. Widać tu powinowactwo z twórczością filmową Andy'ego Warhola oraz obrazami węgierskiego filmowca Beli Tarra. Warhol wprowadził do sztuki powtarzalność, banał, nudę, czemu najdobitniejszy wyraz dają właśnie jego filmy, portretujące w czasie rzeczywistym takie czynności jak spanie (Sleep) czy jedzenie (Eat) albo składające się na przykład $\mathrm{z}$ ośmiu godzin nieprzerwanej rejestracji jednego budynku (Empire). W wyniku takich zabiegów na pierwszy plan wysuwają się nie bohaterowie (żywi czy też nieożywieni) bądź wykonywane przez nich czynności, lecz samo ich trwanie w czasie. Bela Tarr z kolei słynie z opowiadania za pomocą niezwykle długich ujęć. Znajdziemy takie i u Van Santa, choćby w scenie, gdy bohaterowie wloką się resztkami sił, podczas gdy gdzieś na horyzoncie wstaje słońce i stopniowo robi się coraz jaśniej. Poprzez zastosowanie takich środków autor prowokuje widza do poddania się kadencji obrazów. Da się bowiem w Gerry'm zauważyć naprzemienny rytm, budowany na opozycji dalekich i statycznych ujęć skontrastowanych ze scenami, gdy kamera jest blisko bohaterów, idzie (bądź biegnie) wręcz razem z nimi. Podobnie u Becketta. Antoni Libera pisał o muzyczności jego drama-

[21] J. Błoński, op. cit., s. 19.

[22] Ibidem, s. 16.

[23] P. Czapliński, Nuda przedstawiona albo proza najnowsza wobec istnienia, w: Nuda w kulturze, pod red. P. Czaplińskiego i P. Śliwińskiego, Poznań 1999, S. 256.

[24] T. Sobolewski, op. cit. 
tów (m.in. Końcówki) [25], ale bardziej odpowiednim określeniem na obecną tam grę strukturalnych zależności jest chyba właśnie rytmiczność. To zapętlony, powtarzający się rytm zdaje się więzić bohaterów Van Santa w czasoprzestrzennej pętli, co podkreśla wręcz spinająca film klamra - jadący autostradą samochód. Podobnie kolista forma cechuje utwory Irlandzkiego pisarza - Końcówka przecież nawet zaczyna się od słów obwieszczających koniec, a Vladimir i Estragon w finale swojej sztuki czekają na Godota niemal dokładnie tak samo, jak robili to na jej początku.

Unieruchomiony w ten sposób czas - niekończąca się teraźniejszość pustki - przywodzi na myśl zjawisko nudy, zwłaszcza w ujęciu Josifa Brodskiego. Dla niego nuda jest „oknem na czas, na te jego cechy, które zazwyczaj lekceważymy, najczęściej za cenę równowagi psychicznej. Krótko mówiąc, jest oknem na nieskończoność czasu, to znaczy na naszą w nim znikomość" [26]. Okazuje się więc być to stan szczególny, w pewnym sensie błogosławiony. Ale oświecenie, które ze sobą niesie, jest zarazem niebezpieczne, uświadamia bowiem oświeconemu jego własną małość, błahość. Działa trochę jak sokratejski daimonion - wewnętrzny głos, który staramy się na co dzień zagłuszyć, a który uzmysławia nam naszą niewiedzę. Według Przemysława Czaplińskiego nuda może, ,jako powszechne zapośredniczenie czasowości, nieskończoności i wolności [...], nabrać charakteru doświadczenia, które odsyła nas do podstawowych wymiarów naszej egzystencji” [27]. Jest więc ona doświadczeniem pokrewnym temu, do czego dążą bohaterowie filmu Van Santa. Również dlatego, że - jak każde zachowanie transgresyjne - niesie ze sobą ryzyko. Przekraczając granice, można spodziewać się objawienia, ale i należy liczyć się z możliwością poniesienia kary. Czy ceną za wolność nie jest bowiem groźba zbłądzenia?

Nuda w ujęciu potocznym to stan emocjonalny nacechowany negatywnie. Kojarzy się z bezczynnością i bezproduktywnością, pojawia się w sytuacji monotonii i braku bodźców. Kto się nudzi, grzeszy obojętnością i brakiem zainteresowania. Mówimy, że można „zanudzić się na śmierć". W europejskiej tradycji kulturowej znajdziemy przykłady na to, że poddanie się nudzie uznawano za rodzaj nietaktu, błąd. Uchodziła ona nieraz za niepożądane kuriozum, a czasem za zjawisko niebezpieczne wręcz[ $\left.{ }^{28}\right]$. Nie tylko zresztą w Europie - podob-

[25] Akcja sceniczna Końcówki ma według Libery „swój sens formalny, rodem właśnie z muzyki. Przebiega mianowicie w myśl zasad arytmetycznych i struktur stosowanych w kompozycjach dźwiękowych". A. Libera, op. cit., s. LXXIX.

[26] J. Brodski, Pochwała nudy, przeł. A. Kołyszko

i M. Kłobukowski, Kraków 1996, s. 91.

[27] P. Czapliński, op. cit., s. 266.

[28] Michał Paweł Markowski, kreśląc historię nudy jako przedmiotu dyskursu naukowego, przytacza pierwsze próby zdefiniowania tego zjawiska. Pewien niewymieniony z nazwiska szwedzki dyplomata z XVII wieku uznał ją za twór człowieka nieistniejący w naturze, a wynaleziony ku ludzkiemu nieszczęściu. Dla Pascala była ona czarną dziurą grożącą porwaniem w swe odmęty, możliwą jedynie do przykrycia nigdy całkowitego usunięcia. Z kolei w jednym z tomów XVIII-wiecznej Encyklopedii pod redakcją Denisa Diderota niejaki kawaler de Jaucourt opisał ją jako swoistą nieprzyjemność, w zasadzie niedefiniowalną, 
nie bywało w Ameryce, gdzie etos pracy nie pozwalał tolerować tego rodzaju marnotrawnych zachowań[29]. Nie jest to jednak cała prawda o poglądach na nudę. Wielu starało się ją oswoić, widząc w niej krytyczny moment doświadczenia osobistego, dający szansę przekraczania własnych ograniczeń $\left[3^{0}\right]$. Wraz z pojawieniem się takich zjawisk jak czas wolny miejsce nudy w kulturze zaczęło się zmieniać (gdy brak obowiązków, łatwiej poddać się znużeniu). Pod pewnym względem nuda spowszedniała, głównie w wyniku ekspansji kultury popularnej, której naczelną zasadą okazała się seryjność, powtarzalność.

Nie sposób rozstrzygnąć, jakie jest miejsce nudy w doświadczeniu dwójki bohaterów filmu Van Santa. Z jednej strony skłonni jesteśmy przypisać im dążenia emancypacyjne, z drugiej zaś doświadczamy, jak w monotonnej pustynnej scenerii zanika ich człowieczeństwo. Czy nuda dopada mężczyzn wbrew ich szczytnym intencjom? A może na odwrót - intencje te rodzą się dopiero w poczuciu znużenia? Porządek teleologiczny nie daje się tu jednoznacznie ustalić. Które doświadczenie było pierwsze? Nie wiemy przecież nawet, co skłoniło bohaterów filmu do podjęcia wyprawy. Może to nuda wszechobecnej powtarzalności wzbudziła w nich poczucie nostalgii za tajemniczym Czymś? A może dopiero nuda kontaktu $\mathrm{z}$ obezwładniającym bezmiarem pustyni sprowokowała refleksję eschatologiczną, prowadząc do bezpośredniego zetknięcia ze śmiercią? Nuda może być zarówno skutkiem, jak i przyczyną. Dowodzi tego (za Pascalem) Michał Paweł Markowski:

Z jednej strony jest to stale obecny warunek niemożliwości ludzkiego działania, coś, co je paraliżuje i co wytrąca człowieka z jego aktywności, wtrącając jednocześnie w piekło samotności. Z drugiej jednak strony stanowi konieczny warunek możliwości takiego działania[ $\left.{ }^{31}\right]$.

Dlatego nuda zarówno jako doświadczenie stematyzowane w utworze, jak i wrażenie rodzące się w procesie jego odbioru może być doznaniem zgoła pozytywnym.

Tadeusz Sobolewski zastrzega jednak, że Gerry wymaga szczególnego, aktywnego typu odbioru[32]. Domaga się tego praktyka

bo o rysach cokolwiek nieostrych, będącą przyczyną poczucia niemocy i niesmaku. U schyłku tegoż wieku filozof Étienne Pivert Senancour za początek doświadczenia nudy uznał moment, w którym człowiek zaczyna rozmijać się z sobą samym. M.P. Markowski, L'ennui: ułamek historii, w: Nuda w kulturze,

s. 292-306.

[29] „Oparta na purytańskim zakazie acedii i wychylona ku oddalającej się granicy cywilizacji kultura amerykańska dziewiętnastego stulecia nie znosiła nudy podobnie jak natura nie znosi próżni - nastrój bezproduktywnej jałowości był po prostu nie do pomyślenia w ramach obowiązującego wówczas systemu pojęć”. M. Wilczyński, Praca melancholii, czyli o nie- możności nudy. Melancholia w literaturze amerykańskiej XIX wieku, w: Nuda w kulturze, s. 317.

[30] Anna Zeidler - Janiszewska relacjonuje, że Siegfried Kracauer przypisywał jej funkcje emancypacyjne, prowokujące do głębszej refleksji, a Walter Benjamin interesował się tym, jak XIX-wieczne elity intelektualne w osobach dandysów i flaneurów zaczęły ją pielęgnować. A. Seidler-Janiszewska, O konsekwencjach miejskiej nudy. Inspiracje Waltera Benjamina i Siegfrieda Kracauera w badaniach nad geneza masowej rozrywki, w: Nuda w kulturze, s. 345. [31] M.P. Markowski, op. cit., s. 299.

[32] T. Sobolewski, op. cit. 
twórcza przyjęta przez autora. Zarówno Van Sant, jak i Beckett wykorzystują gotowość widza (kinowego bądź teatralnego) do nadawania znaczenia temu, co pojawia się na ekranie/scenie. Ta odbiorcza aktywność zostaje jednak skierowana ku tym elementom, które zazwyczaj marginalizuje się w procesie opowiadania. Widz zmuszony jest do obcowania z nieatrakcyjnymi, fabularnie ubogimi miejscami narracji. W rezultacie komunikat wysyłany w jego kierunku staje się dużo bardziej niejednoznaczny. Odbiorca pozbawiony akcji, którą mógłby śledzić, może skapitulować. Ale może także podjąć wyzwanie postawione mu przez autorów.

Dramaty Becketta zmuszają widza do rewidowania sposobu recepcji dzieła w jeszcze jeden sposób. Widz teatralny pozbawiony jest przecież możliwości manipulowania czasem odbioru, jaką posiada czytelnik; doświadcza dziania się w czasie rzeczywistym i również w czasie rzeczywistym musi reagować. A realizacje sceniczne tych utworów wydają się być uprzywilejowane - teksty dramatyczne z zasady cechuje przeznaczenie do bycia wykonanym. To zaprojektowane działanie nie jest jednak u Becketta pełne - zasadza się ono na braku, który wymaga dopowiedzenia ze strony widza. Brakuje tu dookreślenia zarówno czasu, miejsca, jak i samej akcji, a nawet bohatera - często kalekiego, ułomnego, niekompletnego w swej formie cielesnej (Nagg i Nell z Końcówki, postacie z Komedii, Usta z Nie ja).

Powyższe spostrzeżenia potwierdzają uwagi komentatorów pisarstwa Becketta (również jego twórczości prozatorskiej). Jan Błoński: „między dziełem a czytelnikiem wywiązuje się osobliwa gra, ponieważ chce on koniecznie narzucić głębszy sens temu, co napotyka [...]. Mistrzostwo pisarza polega zatem na uruchomieniu znaczeniotwórczej zdolności umysłu. A także - na dostarczeniu obfitej pożywki działaniom, które nasycają błahość znaczeniem, a przypadek koniecznością” [33]. Andrzej Falkiewicz: „Beckett [...] stworzył [...] dramat, którego «dramatyczność» zasadza się na krytyce i kłótni z widzem; szkielet utworu pozbawiony akcji i przeczący sensom, który staje się dramatem tylko wtedy, gdy widz jakiś sens odnajdzie" [34]. Maurice Nadeau: „Ktoś uważa tę powieść (Molloy) za arcydzieło humoru, ktoś inny - epikę nieszczęścia. Dla niektórych jest to milczenie przetłumaczone na słowa, dla innych literacka ekspozycja kompleksów należących właściwie do psychoanalizy. W rzeczywistości, każdy widzi w niej to, co chce" [35].

Rüdiger Bubner uważa, że doświadczenie estetyczne realizuje się w procesie odbioru - dzieło jest w świadomości adresata nie tylko rekonstruowane, lecz właśnie konstruowane. Było tak zawsze, ale uwydatniły to dominujące w nowoczesnej sztuce tendencje do przezwyciężania i rozbijania jedności dzieła. Bubner wskazuje tu na proces, w toku którego pojawiły się m.in.: kubizm i futuryzm, Du-

[33] J. Błoński, op. cit., s. 30.

[35] Ibidem, s. 104.

[34] J. Błoński i Marek Kędzierski, op. cit., s. 97. 
champowskie ready-mades oraz wszelkiego rodzaju obrazy tworzone z przypadkowych materiałów. Takie podejście odrzuca podstawową granicę między daną realnością odbiorcy a dziełem jako drugą rzeczywistością, jest grą polegającą na tej granicy zacieraniu, dopuszcza sceptycyzm wobec zawartości samego dzieła[36]. Bubner twierdzi, że doświadczenia estetycznego „nie należy pojmować jako czysto biernego przyjmowania czegoś, co oddziałuje na nie z zewnątrz, że trzeba je raczej opisywać - skoro zawartość estetyczna dopiero się w nim konstytuuje - również jako rezultat" [37]. Cechą, która wyróżnia tak rozumiane doświadczenie estetyczne, jest to, że

pozwala wyobraźni myśleć więcej, niż da się objąć w jednym pojęciu. Impuls sprawiający, ,że w myśli dodajemy wiele [takich rzeczy], które nie dają się nazwać”, decyduje o owym szczególnym doświadczeniu, w którym, choć warunkowana zmysłowo nieograniczona wolność intelektualnej aktywności usamodzielnia się i staje się rodzajem gry, której nie ogranicza żadna pojęciowa określoność i która nie wyklucza uczestnictwa żadnego podmiotu [...]. Sztuka istnieje zatem tylko w obszarze aktywności refleksji wywołanej przez pewne zmysłowe obiekty $\left[{ }^{38}\right]$.

Gerry jest jednym z filmów, które ze szczególną siłą legitymują taki punkt widzenia. Obraz Gusa Van Santa staje się dla widza zwierciadłem, w jakim ten może się przejrzeć. Podobnie jak Vladimir i Estragon nie doczekują przybycia Godota - dwaj młodzieńcy w filmie nie osiągają wyznaczonego celu. Jednak ich podróż, podobnie jak czekanie tamtych, nie idzie na marne. Nie dajmy się zwieść wrażeniu bezruchu i bezproduktywnej stagnacji, jakie może się pojawić w zetknięciu z utworami Van Santa i Becketta. Zachodzi tu bowiem szczególne działanie. Zmiana dokonuje się w nas - widzach - właśnie na obszarze refleksji. Błądząc po pustyni wraz z bezimiennymi bohaterami Gerry'ego, uczestniczymy bowiem w poszukiwaniu wrażliwości. Jej obecność wykrywa, niczym papierek lakmusowy, sam film. Być może w toku tego procesu faktycznie zgłębimy jakąś tajemnicę. Własną.

[36] R. Bübner, Doświadczenie estetyczne, przeł. K. Krzemieniowa, Warszawa 2005, s. 38-39.
[37] Ibidem, s. 43.

[38] Ibidem, s. 46-47. 